\title{
ABORTION THROUGH THE LENS OF FETAL PERSONHOOD
}

\author{
Social Meanings and Functions
}

\section{INTRODUCTION}

In the lead-up to the 2016 Republican primaries, Donald Trump asserted that women who seek an abortion "should face some sort of punishment," a comment that was quickly walked back to place the blame on those performing the procedure, once again safely situating the woman as a victim (Diamond, 2016, para. 1; Smith, S., 2017). Since the election, Trump has spoken at "right to life rallies," reinstated the "global gag rule" prohibiting overseas organizations who receive US funding from providing abortions or even basic health information, successfully installed two antichoice Supreme Court Justices, and, more recently, inspired Mississippi to pass a ban on abortions after 15 weeks (North, 2018; Smith, S., 2017; Redden, 2017). Even Bernie Sanders campaigned for Nebraska's anti-choice mayoral candidate Heath Mello, defending his actions as, "I think you just can't exclude people who disagree with us on one issue" (Detrow, 2017, para. 8). In other words, the assault on the right of women to access abortion services continues apace.

However, it was the 2012 election in the United States that really brought abortion once again to the forefront of social issues, with an intensity of rightist discourse not seen since the early 1980s during the conservative restoration. Fuelled by the Tea Party (the precursor to Trump) and its opposition to the Affordable Care Act, politicians and pundits immediately targeted reproductive health services such as contraceptive coverage as a source of their outrage. What made this resurrection of abortion stand out was the lethal language aimed at women as a whole. Everything from dissecting the lives of poor women, to slut shaming, to attempting to define what kind of rape was worthy of sympathy was up for discussion.

Petchesky (2002) connects the presentation of abortion as being ancillary to civil rights to a fragmented political framing in the US regarding women in general:

One result is a compartmentalization of women's movement work into discrete "issues"-violence, reproductive rights, sexuality, girls and adolescents, women in development (economics, work) — without sufficient attention to the vital points where these intersect. (p. 75) 
The public, then, including many leftists, see abortion and contraception as disconnected from the daily lives of the working class because "it's a women's issue." Abortion is presented as an afterthought, as unimportant or a diversionary fringe issue, a bargaining chip for courting conservative voters. Yet far from being a "fringe issue" - as is often presented by the right, center-right, and liberal political spectra in the US - abortion and the larger aim of reproductive freedom is essential for women, who make up a majority of the world's population.

According to Rowland (2004), approximately 60 million women spanning an age range of 15 to their mid-40s live in the US (p. 270). Of that number, 42 million identify as sexually active, not wanting to become pregnant at that particular time:

Research suggests that a sexually active woman between ages 20 and 45 who wants two children, will spend, on average, almost 5 years of her life trying to become pregnant or postpartum, and more than four times that long trying to avoid pregnancy. (p. 270)

About $75 \%$ of women of childbearing age depend on some form of private insurance to cover reproductive health care, with many requiring Title $\mathrm{X}$ funding, which, according to Rowland, is in constant jeopardy due to funding cuts. It is women who bear the physical, social, and emotional brunt of privatized childcare costs in a virtually unresponsive workplace should they decide to have a baby (Smith, 2005, 2017).

Additionally, half of all US pregnancies are unplanned, with nearly a third of pregnancies of married women considered a "surprise" (Joffe, 2011, p. xvi, loc. 83 ; Rowland, 2004, p. 272). Nearly $60 \%$ of women who have an abortion reported using some form of contraception at the time they became pregnant, which is why centrist arguments to outlaw abortion while retaining contraception are flawed strategy (Rowland, 2004, p. 105). Contrary to the image of a young, irresponsible, selfish woman seeking to end a pregnancy so that she can have fun, the majority of abortions performed in the US are for women (married and unmarried) who already have one or more children (Joffe, 2011, p. 145, loc. 1920; Rowland, 2004, p. 294). Even though three fourths of abortions are performed on unmarried women, a good portion of those receiving abortions are married and identify as religious (43\% Protestant, 27\% Catholic), further eroding media stereotypes (p. 289).

It is no coincidence that abortion and contraception have remained controversial, even though these can be counted among the many safe, routine, medical procedures used by a majority of American women. Rosen (2012) pinpoints the continuing controversy to how women are viewed, with ripple effects stemming from key Court decisions starting in the 1960s:

For most of human history, sexuality and reproduction have been intricately yoked together. Birth control, particularly the Pill, ruptured that link and gave women the right to enjoy sex without the goal of reproduction. When the Supreme Court formally ratified that rupture by making abortion legal in 
Roe v. Wade (1973), many people in this country trembled at the possible changes women's sexual independence might bring. (para. 14)

Indeed, Joffe (2011) locates America's uncomfortable relationship with abortion to a larger uncertainty about sexuality itself. Penny's (2011) insightful framing of prostitution as an economic issue references the societal terror conjured by the "notion of women gaining real sexual control over the proceeds of that labor" (p. 20). Objectification in capitalist society requires that women "remain alienated from our sexuality" despite it being a primary "means of survival in the meat market" (p. 21).

For Rich (1986), another aspect of this discomfort with female-driven sexuality involves society as a whole still dealing with women departing from the biologically determined role of the mother. This mother figure has to be all-suffering and asexual. The removal of that suffering means a severe rupture of social and self-identity, which is not tolerated on the Right. Abortion and contraception represent the ability for women alone (not husbands, fathers, boyfriends, male family members, clergy, police, or politicians) to determine whether or not to have children, and the spacing of those children. Males do not have to be involved in the decision at all, though working-class men also benefit from access to reproductive health care. This is simply not acceptable for the right wing who will continue to do everything in its power to marginalize women and erode working class solidarity through reproductive control.

This chapter dialectically examines, from a Marxist Feminist perspective, a specific ideological development in the abortion/contraction controversy distributed through the media, that of fetal personhood. First, an overview of recent abortion legislation will be presented, highlighting recent personhood bills. Next, the ideology of fetal personhood is examined, along with its legal implausibility. Finally, I present four ways that fetal personhood benefits the ruling class by objectifying women, eroding solidarity, increasing surveillance, and justifying public sector cuts as part of austerity.

\section{ABORTION: AN OVERVIEW}

The historical trajectory of abortion legislation has always been contentious, but not necessarily linear. As Casper (1998) explains,

Reproduction is a key site of social control over women and of women's agency, both of which differ by race, ethnicity, class, and sexuality. In the United States and elsewhere, women's reproductive processes are contested and stratified at the interpersonal, biomedical/scientific, cultural, economic, political, and global levels of social life. (p. 10)

Abortion itself was allowable in the early US colonies as well as English common law and the Church prior to the detection of fetal movement, or "quickening" (Rowland, 2004). It was only after the growth of medical knowledge in the 1800s that restrictions against abortion and contraception began to occur, continuing until 
the first challenge in the form of Griswold v. Connecticut in the 1960s, which allowed access to contraception. This paved the way for a further extension of reproductive rights, explored more deeply in Roe v. Wade in 1973.

The Roe decision was ground-breaking, as Rowland (2004) notes:

From this language came the modern notion of 'reproductive privacy' and a shift in the landscape of women's rights. The decision legalized first-trimester elective abortion, setting forth a cleanly-divided trimester framework to be used by the courts in balancing the rights of women against the interests of states. It was an important intersection of law and medicine. (p. 111)

Immediately after Roe, restrictions began. The most invasive was the Hyde Amendment in 1977, which denied federal funding for abortion. The implementation of mandatory waiting periods soon followed. In addition to targeting poor and minority women, laws restricting contraception and abortion services for minors were passed. During this time period of the 1970s and 1980s, women who sought abortions were portrayed as baby-killers, lesbians, and sluts and abortion became a litmus test for conservative politicians. By the 1990s, fetal personhood had already become an integral part of proposed and active legislation, including the 2007 ban on a second-trimester abortion procedure, the first of its kind (Joffe, 2011).

According to Rudolph (2012), the origins of the contemporary opposition to abortion as an organizing feature of the Christian Right wasn't in response to Roe v. Wade at first, but instead had to do with a more obscure reason: protecting the taxexempt status of religion:

In the early 1970s, the U.S. government was looking for ways to extend the provisions of the Civil Rights Act of 1964. The IRS opined that any organization that engaged in racial discrimination was not, by definition, a charitable organization and therefore should be denied tax-exempt status... On January 19, 1976, the IRS...revoked Bob Jones University's tax-exempt status. Bob Jones University sued to retain its tax exemption. It eventually lost at the Supreme Court in 1982 and conservative activist Paul Weyrich sensed the electoral potential of enlisting evangelical voters in the conservative crusade. (p. 17)

Led by Weyrich, other pastors spun the ruling against schools that practiced segregation into an attack on states' rights and religious freedom. During the legal battle, because President Carter was for removing the tax-exempt status from Bob Jones University, evangelicals removed their support from him and put it behind Reagan. Eventually, abortion was latched onto as a way to recruit more centrist liberals away from the Democratic Party when original messages such as lower taxes and deregulation had little sway by themselves.

For all of the talk about its "fringe" status, abortion is a key legislative target. In 2011, roughly 40,000 laws and their accompanying provisions were enacted. Close to 1,000 of those restricted access to abortion (Easley, Jones, Haraldsson, \& Rmuse, 
2013, para. 7). The majority of the legislative activity was at the state level, with 135 of these provisions enacted in 36 states (para. 10). A majority of the provisions restricted abortion services, exceeding all previous statistics on such actions. Of the restrictions, six states enacted bans, three states implemented waiting periods, five states introduced ultrasound requirements, eight states now have bans on insurance coverage for abortion, four states have clinic regulations, and seven states prohibit medication abortion (para. 11).

Baker (2013) notes that ten states have implemented time limits for abortion as low as 20 weeks, based on the notion that fetuses can feel pain (para. 11). Proposals for a 12-week ban are in the works, which would represent the harshest measures to date. Much of this recent legislative activity is due to the outcome of the 2010 midterm elections, where 44 abortion rights supporters in the House were replaced by opponents, with the Senate experiencing seven pro-choice losses (Clark, 2011, p. 28). Added to this is the revised Republican Party platform which states that abortion is opposed in all cases with no exceptions for rape, incest, or risk to the woman's life (Cohen, 2012).

The assault has also targeted poor and working-class women in the form of removal of state funds for abortion services. Currently, 32 states along with the District of Columbia will not allow state monies to be used for abortions, except as a result of incest, rape, or threat to the life of the woman (Smith, S., 2017, p. 21). Those who think that receiving private insurance shields them from these restrictions are wrong, with 11 states enacting restrictions on coverage of abortions (p. 20). This is on top of the 17 states that mandate counseling services prior to an abortion, 27 states requiring waiting periods of 24 hours and 26 states mandating parental consent for minors seeking abortions (p. 22).

Easley and colleagues (2013) readily overturn the notion that the war on women is merely hyperbole or a media stunt by summarizing an array of anti-abortion laws that have been introduced by Republicans: denial of birth control in pharmacies known as conscience clauses (HR 1179), prohibition of all abortion except in cases of incest, rape, or health endangerment (HB 2988, Texas); requiring women to attend "spiritual counselling" before obtaining an abortion (HB 1217, South Dakota); mandating that doctors provide misinformation prior to patients receiving an abortion (e.g. that abortions cause suicide ideation or breast cancer; HB 1166, South Dakota, HB 1210 Indiana, Kansas); conditions applied to access to abortion (the "forcible rape" exempt category, HR 3, New Jersey); denial of insurance coverage for birth control and abortion (Senate Bill 438, Georgia; SB 92, Wisconsin), restricting transport to a facility for live-saving procedures (HR 358, Pennsylvania); effectively banning the teaching of abortion methods in medical schools (federal funding House amendment), onerous clinic and personnel requirements including licensure denial (Kansas, Mississippi, Illinois, Virginia, Louisiana, Minnesota); and using austerity as a rationale for ending abortion, including cuts to or defunding of Planned Parenthood (Minnesota, Arizona, Louisiana, Ohio). 
Many of the anti-abortion laws, whether active or overturned, are directly connected to the fetal personhood strategy (Easley et al., 2013). They include The Pain Capable Unborn Child Protection Act (SB 209, Georgia; Bill 1888, Oklahoma; Nebraska; H.R. 3803, District of Columbia) and the Fetal Pain Bill (House Bill 954, Georgia); Arizona's House Bill 206 which prohibits abortions after 20 weeks (technicalities in the law also classify women as pregnant even prior to conception); Texas' Sonogram Bill (HB 15) which originally required even victims of rape to view images of their wombs prior to receiving an abortion; trans-vaginal ultrasound bills which require women to undergo the procedure before obtaining an abortion (Alaska, Texas, Virginia, Iowa, Alabama); forcing women to watch footage of an abortion before obtaining one (Arizona); outlawing fertility treatments and birth control along with abortion (SB 2771, Mississippi); defending an abortion ban after 20 weeks by viewing a pregnancy as a result of rape or incest as "God's will" (Senate Bill 1165, Idaho); fertilized-egg-as-person bills which would also outlaw contraception (Ohio, Mississippi, Oklahoma); and prohibition of abortion after six weeks (Heartbeat Bill, Ohio).

Some of the legislative actions are directly centered on establishing personhood, such as those in Virginia, Wisconsin, Kansas, and Alabama (Easley et al., 2013). Another strategy is represented by HB1305 in North Dakota, which would make it a Class A misdemeanor for a doctor to perform an abortion based on the gender of a fetus. According to Smith (2013), this is another way of implementing deadlines on seeking abortions (the gender of a fetus can be usually determined at 12 weeks). The fact that these types of laws are often successfully challenged in the courts is beside the point - their very existence shows the continual threat to women's reproductive rights.

Anti-abortion laws and commentary have also begun to traverse the path of establishing punitive consequences for abortion. These include: taxing abortions (H.B. 2598, Kansas); publicly posting identifying information of medical providers and women who have abortions (Life Defense Act, HB 3808, Tennessee); Georgia's illegality of abortions and miscarriages with the death penalty applied for proven violations (amendment to existing state law); women and doctors undergoing abortion as being guilty of committing "feticide" (HB 587, Louisiana; House File 2298, Iowa); a call for public hangings as a "deterrent" for the crimes of abortion, rape, and kidnapping (Representative Larry Pittman, North Carolina); no exceptions for rape, incest or health of the mother who would receive a life sentence with suspicious miscarriages being criminally investigated (House File 2298, Iowa); homicide charges applied to the death of an embryo (House Bill 3517, Tennessee); using ultrasounds to ensure that pregnant rape victims were indeed raped, along with invasive questions by doctors asking about marital and relationship status in the context of the rape (S. 1387, Idaho); forcing women to carry even dead fetuses to term because that's what farm animals do in nature (Georgia Rep. Terry England in support of HR 954 banning abortions after 20 weeks); and legalizing the murder of abortion doctors (South Dakota, Nebraska, Iowa). 
Citing "religious liberty" as a justification, opposition to contraception intensified in the wake of the passage of the Affordable Care Act, which requires that employers and university health plans cover contraception without copays or deductibles (Baker, 2012). Contraception provisions as part of the Obama Administration's health care reform have been challenged in Nebraska, Florida, Michigan, Ohio, Oklahoma, South Carolina, Alabama, and Texas, on the grounds of inhibiting religious freedom (Easley et al., 2013). Indiana has proposed an especially invasive ultrasound bill that would require women to receive two trans-vaginal probes (before and after) in order to receive the RU-486 pill (Strasser, 2013). The use of probes is medically irrelevant since a blood test could verify that a pregnancy had been ended.

\section{FETAL PERSONHOOD: IDEOLOGY \& LAW}

A major organizing aspect of the anti-abortion movement is the notion of fetal personhood, which is the justification behind the bulk of recent legislative efforts. It is important to note that religion, while still a primary influencing factor behind the anti-choice movement, is now joined by medicine as a potential ally:

Part of the reason this has gathered steam in recent decades is something of a convergence of medical science and anti-abortion rhetoric whereby the objective and ostensibly value-free claims of science regarding the fetus are supplementing, even superseding, value-laden religious anti-abortion argumentation. In addition, parental and medical concern for the wanted fetus as patient tends to bolster anti-abortion claims of the personhood, if not primacy, of the fetus. (McCullough, 2012, p. 19)

It is understandable why the notion of fetal personhood has taken a powerful discursive hold in not only the United States, but across the world. What can be more democratic (or even social justice sounding) than everyone enjoying the protections of one's nation, including those most vulnerable and voiceless? To oppose such a thing transforms one into a heartless bully who is no better than the Nazis were, bent on exterminating the "feebleminded" or those not racially fit. Needless to say, when the anti-choice right landed on fetal personhood, they struck gold.

A major factor in the entrenchment of fetal personhood has been medical advances in obstetrics, the use of the ultrasound in particular (Casper, 1998; Joffe, 2011). Joffe (2011) notes the increasingly common practice of parents displaying ultrasound documents as the first pictures of their "baby." Even though most abortions happen in the first trimester with just over 1\% occurring after the 20th week (Smith, S., 2017, p. 16), women are given detailed descriptions of fetal development as a potential deterrent, even going as far as mandating the ultrasound procedure as a condition of obtaining an abortion. Further complicating the picture are physicians who belong to pro-life caucuses of organizations such as the American College of Obstetricians and Gynecologists and groups such as the American Academy of Family Physicians. 
Joffe points out that some of these physicians do not feel obligated to refer patients to those who might provide abortion and contraception services.

Using fetal personhood logic, pharmacists are also able to enact consciousness clauses, where they can refuse to fill prescriptions for contraceptives (including emergency contraception), viewed as threatening the fetus. Catholic-affiliated hospitals are not allowed to perform life-saving abortions or administer abortion pills to rape survivors (even though, according to Cohen (2012), over 30,000 pregnancies are a result of rape (para. 9) due to the prioritization of the fetus. Ginty (2011) outlines the heroic action of hospital administrator Sister Margaret McBride who approved a life-saving abortion, resulting in her excommunication. Rowland (2004) traces the origins of today's fetal personhood ideology to the struggle over access to contraception. In the Griswold case, doctors asserted that the Fourteenth Amendment applied to those yet "unconceived" and that fetuses had an interest in the outcome of the case.

Casper's (1998) research into the medicalization of the fetus is useful in understanding the trajectory of fetal personhood, as well as who composes the antichoice movement. She identifies the fetal personhood movement as part of a broader construct of "fetal politics" that includes

the crafting of a new science called fetology, controversies over fetal tissue research, the emergence of fetal rights in law and ethics, debates about and proscriptions on pregnant women's behavior, a cultural obsession with fetal images, and the relentless pursuit of new reproductive technologies. (p. 4)

Casper explains that success rate of fetal surgeries is extremely low. Of those fetuses that survive and are eventually born, many are maimed for life, assuming that that life is a long one to begin with. There is also a social class dimension to this, as these are extremely expensive procedures that only the wealthiest (and white) can afford. As the media focuses on the miraculous medical achievements of fetal surgery, it also masks the growing heath care crisis as more and more people are unable to achieve basic health services. The cultural myths surrounding motherhood often cover the reality of drastically uneven access to basic prenatal care, for example. As these medical advancements close in on women, rendering them invisible in favor of the fetus, a darker ethics emerge, which Casper (1998) explores. If a woman declines the option of fetal surgery, is she then culpable in the death of her child? Or, harder to consider, is if a woman opts for fetal surgery even knowing that her child will be profoundly disabled the rest of her/his life. Apparently, that type of "choice" is fine with the Right.

New (2013) speculates that attitudes toward abortion are tied to views about the morality of premarital sex, with hardline Catholics and evangelicals taking the most oppositional stances against both. The impossibility of implementing controls over sexuality in the face of a secular society appears to perplex New, who remains against abortion: 
I always remind pro-lifers that a promiscuous society will never support significant restrictions on abortion. While pro-lifers are good at talking about fetal development and personal responsibility, we are less comfortable with subjects such as sexual activity and contraception. Indeed, it is doubtless more difficult to advocate for sexual restraint than for the unborn. However, this is a battle in which pro-lifers must continue to engage if we are to succeed in our goal of providing legal protection to all unborn children. (para. 3)

Yet Marty (2013) points to surveys that show that close to $95 \%$ of adults have had premarital sex, with a respectable $60 \%$ not viewing such relations as sinful. For Marty, the strategy of ending abortion by trying to convince people that premarital sex is wrong seems like a herculean task at best. What is interesting is how New (2013) tentatively acknowledges that it is easier to talk about the fetus than to broach the topic of adult sexual conduct, pointing to some of the psychology behind the anti-abortion movement and reasons for its staying power.

For McCullough (2012), there are only two outcomes of the fetal personhood movement. The first is one where the concept of citizenship becomes so broad as to be rendered null. If eggs and sperm can be human beings entitled to rights, property, etc., then the legal implications lead quickly to inertia and an inability to apply universal definitions of citizenship to a range of situations. The second outcome is one of dystopia aimed at women, along the lines of Margaret Atwood's (1998) The Handmaid's Tale. McCullough (2012) describes the aftermath of the fall of communism in Poland and how it contributed to the country making abortion unconstitutional, enacting a "Poland's traumatic transition away from communism played into this portrayal of the fetus as a democratic citizen fetus - a kind of blankslate citizen, or future citizen, onto which the hopes and dreams of the nation could be projected," (p. 20). McCullough further emphasizes that in the case of Poland, fetuses were not simply transformed into citizens, but the purest form of citizen: the "innocent" person.

Rowland (2004) reviews two clauses of the Fourteenth Amendment relevant to the issue of abortion and women's rights: The Equal Protection Clause and the Due Process Clause. There are two forms of due process, procedural (which has to do with compliance before the intervention of state or federal authorities), and substantive (having to do with previously undefined concepts of liberty). What fetal personhood ideology has done is attempt to extend these same protections to fetuses, embryos, and even eggs. Reacting to these efforts, Crist (2010) distinguishes between "person" and one who is granted constitutional rights, noting that fetal personhood laws fall apart under legal analysis:

Personhood is not a one-dimensional construct. In fact, there are different types of legal personhood, and not all of them fall within the Fourteenth Amendment. In other words, the fetus can be a "person" in some legal ways, but not a "person" of the type contemplated by the Constitution. Thus, we can 
refer to the fetus as a person without necessarily granting it a constitutional right to life. (p. 862)

Crist distinguishes between natural persons, i.e. human beings viewed as worthy of dignity for simply being human, and juridical persons, non-human entities who are afforded legal protections such as corporations:

The fetus, like the corporation, is not entitled to protections because of what it is innately. Instead, the law recognizes that there is a natural person, the mother, who has fundamental interests at stake. Her rights are invested in another entity, the fetus. The law gives that entity juridical personhood to ensure that the rights of the mother may be secured, just as the law gives the corporation juridical personhood to protect the rights of the shareholders. (p. 865)

A law can refer to a fetus as a "person" but that doesn't necessarily mean it is granted a right to life via the Constitution.

Crist therefore appears to have full confidence in Roe's standing:

Even if a legislature wanted to create full fetal personhood, it would be without power to do so. Simply put: fetal laws do not confer personhood upon the fetus because procedurally, they cannot... The Supreme Court has already made clear that the fetus is not a "person" "under the Constitution, and thus is not entitled to protection from deprivation of "life, liberty [or] equal protection of the laws." Legislatures cannot declare otherwise, since this would be in derogation of the Constitution, as interpreted by the Supreme Court in Roe v, Wade. Thus, if a legislature attempted to establish natural fetal personhood, its law would simply have no effect unless Roe's essential holding was overturned. (p. 867)

This analysis points to a rationale behind attempts to overturn Roe. If it were to fall, then the final barrier to fetal personhood would be achieved, and the end of reproductive freedom. Of course, one could argue that the entire purpose of personhood laws is to end abortion, so both means would point to the same end.

Crist (2010) also asserts that there does not have to be a conflict between fetal homicide laws and access to abortion. Much depends on the purpose of the laws. For example, feticide laws are in place because of a recognition of the unique biological situation of a pregnant woman. They are not in place to challenge the right to an abortion (even though supporters for such laws may have that intent in mind). California and Maryland are two states that make it explicitly clear that feticide and abortion are separate situations, with abortion's status remaining legal. There is also the matter of abortion and feticide laws being focused on the rights of the actor (the woman and the attacker, respectively) and not the object of the action (the fetus). Under the law, a woman deciding to obtain an abortion is not held to the same legal consequences as someone who murders a pregnant woman and her fetus:

If we take this actor distinction one step further, we come to the issue of consent. Forgetting entirely that the fetus even exists, abortion is a medical 
procedure performed on the autonomous body of a pregnant woman. Bodily invasion requires consent. This is the very difference between a battery and a hug. When a woman chooses abortion, she consents to the actions taken upon her body. Women do not consent to brutal attacks that end their pregnancies. (p. 882)

The problem with Crist's analysis, however, is that it assumes that the matter of the actor is settled in terms of public perception. For Crist's assurances to hold up, there has to be agreement that consent is the purview of the woman. Yet anti-choicers continually assert a false equivalency of personhood by arguing, "what about the fetus' consent-do they have say?" What anti-abortion activists have essentially done is to craft a fetal separatist movement where not just embryos, but eggs are prioritized over grown women (Burroughs, 2012). Ultimately, relying on Roe's legal protections is a shaky proposition in the face of a group that is not really motivated by who is represented in abortion law, but by limiting women's rights - a group who has made it clear they will use any form of legislative discourse to achieve that end.

\section{OPPRESSIVE OUTCOMES OF FETAL PERSONHOOD}

When approaching history from a dialectical perspective, it becomes clear that rather than remaining static, laws shift and change under capitalism to maintain key benefits for the ruling class (Marx, 1845). In the case of reproductive rights, to a large degree the ruling class appears tolerant of the existence of contraception and abortion on a social level. That doesn't mean, however, that they do not benefit from its continued opposition by conservative groups. For example, the resurrection of attacks on abortion and contraception during the lead up to the passage of the Affordable Care Act was utilized by the ruling class who has a key interest in making sure that national single payer healthcare does not happen. This section looks at four key ways that the construct of fetal personhood contributes to the continuing oppression of women, in particular working-class women. These include objectification, erosion of solidarity, increased surveillance, and justification for slashing the public sector.

\section{Objectifying Women}

As Rowland (2004) points out, “An independent female sexual identity, one devoid of maternal instincts or disinclined to have heirs, has been perceived throughout history as nothing less than dangerous" (p. xxvii). Fetal personhood represents a powerful form of objectification of women, that of rendering them invisible so as to remove some of that danger. Casper (1998) describes how the fetus being placed front and center has automatically removed the adult woman from the picture:

Like the oversized fetus in 2001: A Space Odyssey, fetuses are increasingly portrayed as free-floating and larger than life. Where fetuses were once confined to anonymity and invisibility inside pregnant women's bodies, the 
fetus has now gone solo. Never mind that most fetuses cannot live outside of a woman's body. Contemporary fetal representations routinely erase women's agency and bodies. (p. 16)

Understanding how objectification functions can be helpful in situating the abortion issue. According to Nussbaum (2010), there are seven key ways that peoplewomen especially — can be objectified by those in power. Though Nussbaum was speaking to the objectification of women in Internet forums, these different means of objectification can also be applied to the fetishizing of the fetus over the humanity of the woman. First, is instrumentality, where those who do the objectifying envision their victim as nothing more than a means to an end. In the case of the anti-choice concept of pregnancy, women are vessels for carrying the fetus. Second is the denial of autonomy, where those who objectify refuse to acknowledge the capability of a woman to make independent decisions. Anti-abortion groups are resistant to the idea of women rationally considering their own bodies in making reproductive health choices, as evidenced by the endless regulations they propose. Third is inertness, where women are viewed as passive, waiting to hear what they need to do next. The framing of "alternatives" to abortion, such as crisis pregnancy centers or adoption, operate under the notion that women are frozen in a perpetual state of indecision when it comes to reproductive choices.

Fourth is fungibility, where women-as-objects are anonymous and interchangeable with each other. The insistence of the anti-choice movement on women carrying each and every pregnancy to term regardless of context is an example of the anti-choice movement objectifying women as interchangeable entities: all pregnancy is the same pregnancy. All children must be welcomed children. Fifth is violability where women who are objectified are viewed as having no boundaries with an assumed permission to invade or destroy. Anti-choice support for trans-vaginal ultrasound bills and denial of abortion in the case of rape are prime examples of violable objectification. Sixth is ownership, where women are treated as property. Countless anti-choice propaganda sends the message that women of reproductive age do not fully own their bodies. Instead, those bodies belong to males via the fetus. Finally, the seventh form of objectivity is the denial of subjectivity, where the emotions and life experiences of women do not matter. Certainly, this is most characteristic of the conspicuous absence of women to begin with in the abortion conversation.

Nussbaum (2010) goes on to note that there are three additional forms of objectification which include reducing women to body parts (with abortion, women are walking wombs), reduction to appearance (when women are discussed among anti-abortion circles, those who violate the norms of motherhood are "sluts," including rape victims), and silencing (women are not allowed to have a voice in reproductive decision making beyond the range of birthing options). Autonomy can be more than denied; it can be violated, where "the objectifier forcibly removes, or curtails, the woman's autonomy" (p. 72). The ideological invisibility of women in the abortion debate is therefore a particular form of uber-objectification where 
adult women are forced to the margins of the abortion question. Their presence is unwelcome:

Arguments against abortion have in common a valuing of the unborn fetus over the living woman... The woman is thus isolated from her historical context as woman; her decision for or against abortion is severed from the peculiar status of women in human history. The antiabortion movement trivializes women's impulses toward education, independence, self-determination as selfindulgence. (Rich, 1986, p. xvi)

An example of objectification in action is noted by Davis (2010), who examined the prevalence of males in the profession of editorial cartooning and how this affected the framing of current issues like abortion. Female political cartoonists such as Jen Sorensen tend to highlight the irony of males making decisions about abortion. By contrast, a content analysis of abortion-related political cartoons created by males from 2005 to 2010 showed no images of a pregnant women speaking: "A common device is for the fetus to speak instead of the mother" (p. 20).

\section{Eroding Solidarity between Women}

Fetal personhood is a fundamental attack on the solidarity women can experience through socialist feminist awareness. Sexuality and reproduction are key biological and social ways of shared experience that cut across many boundaries such as age, income, race, ability, and sexual orientation. All humans are sexual beings yet women in particular often bear the brunt of current sexual policies. This is not to say that there are not important differences across these identities when it comes to reproductive rights; just that in the feminist movement of the early 1970s, conversations began to emerge along socialist lines about the need for recognizing that working class women had to maintain control of all decisions regarding their own bodies, regardless of their particular background or identity. This was especially critical in terms of economics. For example, the most economically vulnerable women were the first to be targeted after the gains of Roe v. Wade, in the form of the Hyde Amendment (Joffe, 2011; Rowland, 2004; Smith, 2005). As Smith (2017) points out,

the most typical abortion patient is Black or Latina, in her 20s or 30s, who is living below or slightly below the federal poverty line and already has one or more children. Furthermore, 54\% of abortion patients pay for it themselves, without Medicaid or insurance funding. First trimester abortions can cost from $\$ 400$ to $\$ 1500$ according to planned parenthood. (p. 16)

Rape is often used as a dividing line between women, with advocates of fetal personhood questioning the long-held notion of rape being an exception to banning abortion even among many anti-abortion advocates. The endless parsing of imaginary categories of rape into "acceptable" and "unacceptable" or "forcible rape" 
versus some less violent version is a testament to slut shaming at its finest. Former Republican Missouri State Senator Todd Akin's famous quote about legitimate rape and abortion comes to mind: "That's [pregnancy as a result of rape] really rare. If it's a legitimate rape, the female body has ways to try to shut that whole thing down" (Cohen, 2012, paras. 2-3). In 2006, Republican South Dakota State Senator Bill Napoli supported legislation to ban all abortions in the state. When asked if he would allow for any exceptions to the ban, he went into great detail adding conditions to an exception for rape:

[She] would be a rape victim, brutally raped, savaged. The girl was a virgin. She was religious. She planned on saving her virginity until she was married. She was...sodomized as bad as you can possibly make it, and is impregnated. I mean, that girl could be so messed up, physically and psychologically, that carrying that child could very well threaten her life. (Joffe, 2011, p. 62, loc. 882-886)

These statements carry with them several cultural assumptions about women and sexuality: that somehow rape is more traumatic and unwanted if one isn't a virgin, that extra-vaginal rape is more violating than the "right way" to have sex, that lifestyle choices somehow "bring on" rape, and that pregnancies as a result of rape imply a form of consent on the part of the victim who is therefore selfish for seeking an abortion. The obsession with locating true victimhood is not much different than the quest for the perfect innocent person: the fetus.

Joffe's (2011) interviews with abortion clinic staff and patients revealed heartbreaking accounts of isolation and eroded solidarity between women, particularly patients who considered themselves anti-abortion:

"I am a Christian-I am not doing this casually," one woman said, clearly suggesting that others in the waiting room were not so thoughtful or moral. Another woman said, "I think that people should be held accountable for their actions, and a lot of times it's the convenience of the situation that makes it easy...to get an abortion, and if I wasn't the person that I was, I mean, this would be real easy, just real simple...I wouldn't support them because... it might become a habit for everyone." (Joffe, 2011, p. 116, loc. 1565-1570)

The anti-choice women had to reconcile the contradiction of their own antiabortion beliefs and narratives with the stark reality of sitting in the clinic, facing the very situation they had openly derided others for in the past. Many of the women Joffe interviewed already had children. The only way out of their moral contradiction was to distance themselves from other patients by ascribing legitimate reasons to their own choices while framing other women were being promiscuous. For Joffe, this represented manifest shame, in particular as the women often expressed concern that someone might recognize them in the clinic. Indeed, many of the women deliberately chose to travel long distances to ensure that would not happen. After 
their repeated encounters with anti-choice women, clinic staff wryly described the three exceptions for abortion as being "rape," "incest," and "mine."

The Right has also been using multicultural strategies in their divisive attacks on reproductive rights. Kamoa (2012) provides the example of how homophobic laws and policies are presented as a way to stem the time of "Western" secularism that is targeting "Christian" populations in African countries. This successfully plays on legitimate concerns of the ravages of colonialism on the part of Western nations. Mixed into the message of resisting Western forces, however, is extreme nationalism, as in the case of Zambia's "kill the gays" laws. As Kamoa puts it, "this deep-seated view of LGBT rights as a neocolonial import puts Westerners hoping to stand in solidarity with those under threat for their sexuality in a difficult spot" (p. 15).

A similar tactic occurs with anti-abortion laws and policies being promoted to African-American and Latino/a communities with an anti-eugenicist message through websites like blackgenocide.org and groups such as the National Black ProLife Coalition, Blacks for Life, and Human Life International. This decontextualizes the historical and ongoing reality of eugenic overpopulation discourse and policies such as sterilization, overwhelmingly aimed at majority world countries and AfricanAmericans in the US (Rich, 1986). Additionally, Martinez (2002) notes the shortsightedness of mainstream feminist organizations who often assume that women of color are anti-choice or are not interested in reproductive rights issues:

The problem has often been rooted in a racist arrogance underlying the attitude of many Anglo women toward Latina views on reproductive rights... If we look more closely at Latina views, we find that reproductive freedom is a major concern of Latinas and not some taboo subject or minor matter. In 1977, when Congress ended federal funding of abortions, the first victim was a 27-year-old Chicana-Rosie Jimenez from McAllen, Texas, daughter of migrant workers - who died at the hands of an illegal abortionist after six days of suffering. (p. 273)

These collective efforts of the anti-choice movement see eroded solidarity as a key victory for anti-working-class policies as a whole.

\section{Expanding Surveillance}

Marcotte (2013) notes that part of the long-standing strategy of a focus on fetal personhood has been the ability to cultivate sympathy for an embryo without appearing to be too harsh in one's responses to women who seek and obtain abortions, or, as she explains, "Claiming they don't believe that women who get abortions are murderers even while calling abortion "murder" has been a huge part of the antichoice movement for years" (para. 6). For example, when pressed as to who should be penalized for seeking an abortion if the procedure were to become illegal, the past response was a call for punishing the doctors performing abortions (Rowland, 2004). 
The woman was carefully avoided as a topic of conversation so as to distance the anti-choice movement from appearing to be anti-woman.

To maintain this line of messaging, the woman, who has no ability to think independently concerning medical decisions (regardless of her age), has to "fall prey" to the malicious intentions of a highly funded abortion network. She should not be to blame, just the liberal, anti-family feminists and the medical establishment who deliberately target the most vulnerable. The default position sustaining this thinking, of course, is that all women "naturally" want to have children so something malicious and out of the ordinary must be at work if a woman seeks an abortion or even oral contraceptives.

However, a recent shift has emerged where we are seeing calls for punitive actions against women who seek abortions (Joffe, 2011; Marcotte, 2013). Marcotte (2013) describes efforts in Iowa to introduce a bill that would define abortion as murder, and require the appropriate legal response aimed at women who engage in such murder. The bill also reaches further by targeting oral contraceptives:

The point of this bill is, simply put, to throw women in jail for "murder" for deliberately ending pregnancies - and quite possibly for trying to prevent them, as many anti-choicers continue to insist, despite the evidence against them, that the pill and emergency contraception work by "killing" fertilized eggs...The language of this is quite expansive. They're not only counting women who reach out to legal providers for abortion as "murderers," but also women who go online and buy drugs for this purpose. (para. 4)

Marcotte (2013) speculates that this recent attitudinal shift is due to a growing number of women taking matters into their own hands, including seeking in-home use abortion remedies obtained online or traveling to Mexico to have the procedure done. Women have had to do this because of within-state barriers such as mandatory waiting periods, clinic closures, and economic constraints in the wake of the Hyde Amendment (Rowland, 2004). An increasing number of women independently seeking abortions through other means contradict the stereotype of helpless victims who are prey to evil feminist forces and nefarious doctors. It turns out that a significant number of women were not waiting for anti-abortion laws to "change their minds" and are not interested after all in carrying an unintended pregnancy to term, including many women who identify as anti-choice (Joffe, 2011). Marcotte (2013) feels that this has created a gloves-off attitudinal shift in the anti-choice movement, laying bare its deep misogyny in its call for imprisoning women who do not want to be pregnant and insist on defying the natural order of things.

Initially, fetal homicide laws were designed as part of a recognition by law enforcement and social services agencies that pregnant women faced increased crime risk, including domestic violence (Jones, 2013). What has happened instead is that fetal homicide laws have been used punitively against pregnant women, specifically those who are from marginalized groups: 
These laws shifted the balance of power in favor of the state and the language of the debate began to change. Developing fetuses so clearly defined by the Justices in Roe v. Wade became "unborn children" in need of the protection of the state. Child abuse statutes were used to bully or prosecute women in aggressive, heavy-handed campaigns undertaken - as often, no doubt, in the stated effort to "help people" — as part of a larger political effort intended to change the nation's perspective on "unborn children" by taking aim at the easiest targets: poor, downtrodden, drug-and alcohol-addicted women. (Rowland, 2004, p. 318)

Fetal homicide laws essentially created the category of the unborn human, tried apart from the mother carrying it. What this resulted in was making women subject to the control of the state and their actions placed under intensified surveillance (Jones, 2013).

The problem is that fetal personhood immediately throws us into a competing rights framework where the more rights the unborn receive, the fewer rights the woman carrying the fetus is entitled to (McCullough, 2012). For example, while citizens are afforded protections by the country in which they live, they are also at the same time granting the state access to engage in particular legal behaviors such as surveillance, seizure of property, and access to one's home, etc. Those who propose a fetal personhood legal framework seem to want to transfer all of the protections of citizenship to the fetus, with all of the intrusion-oriented state functions falling to the adult woman who is carrying the fetus. The woman then serves as an appendage whose sole purpose is to absorb the trials of citizenship without question. On the other hand, the fetus experiences no legal sanction whatsoever.

Feticide laws exist in 38 states (Cohen, 2011, para. 11). Of these states, 10 set boundaries at viability while 21 states count the entire pregnancy as prosecutable (Crist, 2010, p. 858). Burroughs (2012) notes, "The state could charge and imprison women who harmed their fetuses by using over-the-counter medications, smoking, or drinking alcohol. The feticide statute could be construed as covering a full range of pregnant woman's behavior" (p. 47). Substance abuse during pregnancy is viewed as grounds for civil convictions in Minnesota, South Dakota, and Washington. More than 200 women have been arrested based on fetal separatist convictions (Rowand, 2004). A majority of these women are minority and poor (Cohen, 2011; Rowland, 2004; Tilly \& Albeda, 2002).

Burroughs (2012) and Cohen (2011) relate the situation of Bei Bei Shuai, who had attempted suicide during her pregnancy in reaction to finding out her boyfriend was married and planning to leave her. She was stabilized but her fetus died a few days after being born. Not long after, Shuai was arrested and charged with attempted feticide. Indiana's law recognizes the fetus the same as a person-since Shuai's fetus' death was viewed as a result of her attempted suicide, she is being charged according to the law. The impact of the Shuai case is far-reaching in terms of not only prosecution, but surveillance as a whole. According to Jones (2013), this could 
create a legal precedent that would make every woman legally responsible for the outcome of her own pregnancy. This could include giving police the authority to determine which miscarriages and stillbirths would garner investigation and possibly arrests. If Roe were to be overturned, women who choose to end their pregnancies by any means necessary would be charged with murder.

McCullough (2012) outlines several examples in New Zealand of personhood actions such as proposing to assign each fetus a registration number tied to the national health care system and child protection alert systems where pregnant women who are victims of domestic violence or take part in harmful behaviors would be placed on a special watch list. Along a similar vein, the high rates of arrest among minority women in the US for fetal harm are not due to minorities using drugs at a greater rate than whites, but because hospitals in poor neighborhoods automatically perform infant toxicology screenings (Cohen, 2011). Rowland (2004) relates an extreme case of fetal privileging in a Massachusetts criminal trial where, as part of the defense strategy, a woman had to stand by and listen as her rapist and kidnapper accused her of being a baby killer because she once attended a pro-life rally.

Increased surveillance also extends to every habit of a pregnant women being placed under intense scrutiny. As Joffe (2011) notes,

The antiabortion movement has long recognized the power of outing abortion patients as a means of discouraging other potential patients. This explains the movement's numerous efforts to photograph the license plates of cars in clinic parking lots and film those entering and leaving the clinics. (p. 116, loc. 1563-1564)

This form of monitoring has extended into proposed laws, such as the Texas Administrative Code (2012), which requires that abortion providers gather detailed information (assured to remain confidential) from their patients in a 16 point list including date of last menstrual cycle, demographic information, number of previous abortions, and if the patient was given the sonogram results prior to the abortion. Grimes (2013) reports that the Texas Department of State Health Services did not consider the feedback of experts to revise these invasive rules, but instead took action by enacting the Texas Administrative Code, based on the input of 10 individuals, all men, including state legislators and representatives of anti-abortion groups.

The function of fetal personhood laws is also tied to nationalism (McCullough, 2012). As one fights to preserve the national identity of citizens" then the elevated position of the innocent person only aids in the move to a fascist concept of the correct citizen, and the need for outside groups to rush to the aid of the most vulnerable. Cohen (2011) quotes Samuel Casey, who heads the Legal Christian Society:

In as many areas as we can, we want to put on the books that the embryo is a person...that sets the stage for a jurist to acknowledge that human beings at any stage of development deserve protection - even protection that would trump a woman's interest in terminating a pregnancy. (para. 13) 
Indeed, much anti-immigrant rhetoric in the United States refers to declining birth rates of whites as a point of collective anxiety, as in a White Extinction Awareness Blog post linking demographic changes to negative social outcomes (Facts About White Decline, n.d.). The fact that US birth rates across all racial and ethnic groups are dropping overall (Wetzstein, 2013) appears to be missed by contemporary racists who are all too eager to link abortion to social decline.

Ultimately, it becomes difficult to disconnect the use of abortion restrictions to justify increased surveillance of poor women, as Rowland (2004) notes:

In addition to being written by middle class Americans, these laws are supposed to appeal to middle class Americans. For soccer moms and PTA parents. For the "middle of America" and people who have settled - usually comfortably - into child rearing and, who, therefore, cannot imagine, or don't care to consider, the harsh realities of other people's lives. It is toward these people that state officials have aimed when announcing the prosecutions of poor, urban and mainly minority women for drinking or living out the tragedies of addiction while pregnant. It is for these people - the middle-class parents - that graphic arguments about "partial birth" abortion are made and for whom placards were waved. (p. 331)

As Coontz (1998) has pointed out, any time a social policy is implemented along the lines of moral justification, as in the family values movement's vision for America, the sanctions invariably fall hardest on the most vulnerable, leaving the ruling class relatively unscathed, because exceptions are always granted for their situations or they have the means to locate solutions on their own. In the case of feticide laws, poor and minority women bear the biggest brunt of the sanctions (Tilly \& Abeda, 2002).

We are facing a situation where, in an era of intensified privatization, women's reproductive organs are becoming public spaces. As soon as a fetus is defined as a person, women are automatically put under surveillance and control:

Given that women's reproductive role has long been a basis for inequality and inferiority under the law, a good case can be made that transforming the fertilized egg into a citizen is a way of reinstating at least some of the control over women that has been lost in the wake of the sexual revolution and the pill. Rather than controlling women directly, that control is now exerted on behalf of an innocent fellow citizen. (p. 21)

Thesee (2013) views the panoply of violence against women as "misogynistic tyranny," (p. 192) where the family is the initial portal of control of women. This control is then buttressed through laws and institutions. Fetal personhood is a perfect mechanism for justifying intensified surveillance of women in general, all in the support of the security state as a whole. 


\section{Supporting Public Sector Attacks}

According to Baker (2012), public sector attacks aimed at women are coming from a variety of fronts, including churches, corporations, conservative politicians at the state level, and high-profile media figures such as Rush Limbaugh and Sean Hannity. For example, Congress aimed to transform Medicaid into block grants, which would result in drastically cutting funding to the program. Medicaid recipients are overwhelmingly women from low-income backgrounds, $70 \%$ of recipients, to be exact (p. 31). Fetal personhood is used as a justification for ending access to contraception and abortion, which directly impact women economically:

Once the government wins the right to deny aid to women who have children while on welfare and to otherwise limit the reproductive rights of poor women, it becomes that much easier to tamper with the reproductive rights of all women. The pattern already exists. Shortly after 1973, when the Supreme Court (in Roe v. Wade) granted women the right to an abortion, the right-tolife forces won passage of the Hyde Amendment, which forbids the use of Medicaid dollars for abortions. Since then, abortion foes have successfully limited the reproductive rights of women regardless of their economic class. Welfare reform follows suit. (Abramovitz, 2002, p. 224)

In the United States as well as the rest of the world, women make up the majority of low-wage, no-to-low-benefit, service industry work and public-sector workforces (Madland \& Bunker, 2012; Minimum Wage Fact Sheet, 2013; Vivas 2013). Women are also overwhelmingly negatively impacted by cuts to entitlement programs such as social security and welfare (Schilling, 2013; Vivas, 2013). Because cuts to abortion and health care services are often connected to the wider attack on the public sector as a whole, understanding fetal personhood takes on immediate relevance, as Cohen (2011) articulates: "Todays feticide laws extend the assault on reproductive rights just as more and more women face unemployment, eviction, and the slashing of public services - in other words, just as the potential need for abortion grows" (para. 19).

Indeed, the very structure of our privatized health care system contributes to the stigmatization of women who seek abortion services. In the United States, over 90\% of abortions occur in clinic type settings, with the remainder happening in hospitals and through private doctors' offices (Joffe, 2011, p. 48, loc. 694). Compounding the problem of access, there has been a drastic reduction in the number of places where women can obtain an abortion. Over $80 \%$ of American counties have no abortion provider, even though roughly $33 \%$ of women between 15 and 45 live in those counties (Rowland, 2004, p. 288). The Catholic Church operates four out of ten of the largest health care entities in the US, further restricting medical services such as abortion and contraceptives (p. 289). Catholic hospitals are now the largest source of non-profit health care in the US with 1 in 6 patients treated annually (Ginty, 2011, p. 32). Joffe (2011) also notes that many women who do have private health coverage for abortion choose not to use it for fear of leaving a paper trail for others to find out. 
In Europe, by contrast, abortion is a routine procedure, occurring in public hospitals insured by national health care systems. Because abortion is automatically part of national health care, harassment is minimal. This points to the emptiness behind Democrats framing abortion as merely a matter of "choice," because women from different income backgrounds do not have the same type of options when it comes to reproductive health care:

Choice has to include having all the healthcare services and information that enable a woman to make her own decision freely... While a Medicaid-funded abortion may be hard or impossible to get in some states, sterilization services are provided by states under Medicaid, and the Federal government reimburses states for $90 \%$ of those expenses. (Martinez, 2002, p. 273)

Much of the discourse surrounding the controversy that emerged after the passage of the Affordable Care Act in the US focused (in varying degrees of severity and insult) on the construct of decent, hard-working, middle class Americans having to support the sexual peccadillos of poor, slutty women who were a burden on the system. Joffe (2011) explains how this plays out against the larger context of a declining social safety net for the working class as a whole:

Women who otherwise have a great deal in common-because of the failures of both government and the private market to meet many families' needs-are separated by their positions on abortion. Even people who are profoundly antichoice don't have health insurance and are losing their pensions and can't send their kids to college...conservatives' focus on abortion and 'bad mothers' has led to a situation where it is more acceptable to deny welfare to 'bad mothers' and where it is more acceptable to have the U.S. be the only industrialized country without paid parental leave. (pp. 141-142, loc. 1876-1880)

It becomes all too clear that the nuclear family construct is no longer sustainable for a growing number of women (Coontz, 1998; Smith, 2005). Yet Kandiyoti (2002) speculates that the motivation of a good number of female anti-abortion activists is due to their resistance to separating sexuality from reproduction because they feel this separation lets men off the hook in terms of family responsibility. In the absence of a supportive public sector (such as childcare), many women attempt to resurrect the nuclear family instead as a solution to the problem of men who abandon their children.

Kaplan (2002) identifies nostalgia for the nuclear family and "good mothers" as going hand in hand with an intensified decrease in the interest of existing childrenparticularly children from lower income backgrounds - along with hostility toward their mothers. The pro-life position apparently does not extend to poor women's rights to have children. Additionally, "good families" are those families who do not bother the rest of society with their economic problems. Good families take on all expenses silently and without complaint. Joffe (2011) notes how compared to other countries which view childcare as a socialized duty, a virtual consensus exists in the 
US that only people of means should have children. Rich (1986) expresses the grave limitations of this perspective:

A movement narrowly concerned with pregnancy and birth which does not ask questions and demand answers about the lives of children, the priorities of government; a movement in which individual families rely on consumerism and educational privilege to supply their own children with good nutrition, schooling, health care can, while perceiving itself as progressive or alternative, exist only as a minor contradiction within a society most of whose children grow up in poverty and which places its highest priority on the technology of war. (p. xii)

\section{CONCLUSION}

On May 15, 2019, Alabama Governor Kay Ivey signed the most restrictive antiabortion law in over 40 years. Citing God as leading her to decide to sign, the law would make abortion a felony, with no exceptions in the cases of rape or incest (Madani, 2019). It is way past time for us to act. With this in mind, a starting point for responding to the assault on reproductive freedom is militancy, not compromise. With the recent connection of the \#MeToo movement and the Women's March to larger issues like reproductive rights, racism, police brutality, workers' rights, and the LGBTQ community, a more direct, insistent discourse is saying, "enough is enough." Even with the Democratic Party finally openly defending abortion and reproductive rights, largely as a response to the Trump administration, women remain unrepresented and relegated to "fringe issue" status in mainstream politics, especially poor and working-class women. Because reproductive laws do not remain static nor adhere to linear notions of progress, access to contraception and abortion remain vulnerable (Rich, 1986). Militancy is therefore necessary.

Planned Parenthood's disastrous decision to "tone down" their language used in advertising and promotions by removing "pro-choice" is an example of how the right wing has successfully eroded reproductive freedom (Abortion Shouldn't be a Dirty Word, 2013; Smith, S., 2017). Because of the ideological (and sometimes actual) attacks on Planned Parenthood clinics, the organization had assumed that a simple removal of terminology would reduce these assaults. This pragmatic approach only emboldens rightist responses and does nothing to ease legal actions on the part of anti-choice groups. Rowland (2004) expresses concerns about this strategy of civility:

Genteel. Polite. With battles that are carefully chosen and calmly planned by a close circle of highly celebrated and roundly educated women who have tended to take the high road. All seem to agree that it is a nice way to handle it: not to stoop to "their level." The problem with this approach, however, is that the high road is rapidly leading women to defeat. (p. 757) 
Joffe (2011) asserts that the contradiction between public discourse on abortion and contraception and polling which consistently shows that majorities believe both should remain legal, is due more to people not wanting to stir up controversy than to any sustained opposition on moral grounds. This leads to the increased stigmatization of abortion and contraception in the media that does not reflect reality as well putting the lives of poor, working-class and disabled women on the line. Since most of the recipients of Planned Parenthood rely on Medicaid public health and Medicaid funding, for this service to end would mean no options for safe reproductive health services (Smith, S., 2017).

In June 2013, Texas women turned the genteel approach on its head. In response to a special session to discuss draconian anti-abortion legislation which would criminalize all abortions after 20 weeks of pregnancy, hundreds of reproductive rights activists (including males in solidarity) gathered at the state capitol to protest the actions of legislators (Culp-Ressler, 2013). Even though Democrats brought legal challenges to the proposed bill, the street action inside and outside the Capitol was the remarkable highlight of the story:
All this led to the "people's filibuster" on the final day of the special session on June 24, in which protesters in the gallery and the Capitol rotunda took over for a filibuster by Democratic Sen. Wendy Davis and yelled at the top of their lungs long enough to prevent the bill from passing by the midnight deadline.
Undeterred this outpouring of protest, Perry quickly called another special session to try to pass the bill. Though many people were no doubt exhausted from the activism during the first special session, pro-choice activists continued to come out in droves during the second special session. They arrived at the Capitol before dawn to fill the House and Senate galleries, they shared their personal experiences about abortion at committee hearings, and they attended rallies and marches throughout the session. (Taylor, 2013, para. 8-9)

Immediately Wendy Davis and her supporters were portrayed as unreasonable, unfeminine, and as not being "respectful" of those in power, even dangerous. The tone policing didn't work. Protests were ramped up after attempts were made to silence the women, with police responding by going as far as disallowing tampons in the legislature (though firearms were apparently fine). This only resulted in a more abysmal image for the Republican Party, whose support among women was already on shaky ground.

Even though the bill still passed, an important lesson was learned. Fighting back still means something and being loud is the way to get things done. The Texas legislature had assumed that the feminist movement was docile, irrelevant, and too afraid to appear militant or even...feminist! They were wrong. Unmoved by a fetus baiting counter-rally which featured a bussed-in audience and the reality television mega-sized Duggar family, Texas women and others around the country took organizing and protest to a whole new level, using multiple strategies, none 
of which involved compromise or toning down the message. Taylor (2013) quotes one of the activists who had obviously had enough and didn't care about appearing "angry":

It's infuriating and insulting to watch the past 40 years of progress be so aggressively rolled back by those least affected by a bill like House Bill 2. I went to the Capitol not because I believed we could stop the bill from passing, but because I felt the spark of a new movement for reproductive justice, and I wanted to be a part of that energy.

Also, I was really mad, and I wanted to yell. A lot. I wanted the senators of the Texas legislation to hear the enraged voices of the people they so carelessly disregarded. If this bill was passing, it wasn't passing quietly. (para. 25-26)

With the recent resurgence of authoritarian populism and fascism, we can expect an urgent need for more of this type of active resistance. 